\section{Fluid flow in a Porous Scaffold for Microtia by Lattice Boltzmann Method}

\author{
Pedro J. Boschetti1 ; Orlando Pelliccioni' ${ }^{2,3}$; Mariángel Berroterán ${ }^{3} ;$ María V. Candal ${ }^{2,3} ;$ Marcos A. Sabino $^{4}$ \\ *Corresponding author: E-mail address: pboschetti@usb.ve
}

Abstract: The birth deformity of ear, known as microtia, varies from a minimal deformed ear to the absence of auricular tissue or anotia. This malformation has been treated by reconstructing the external ear, mainly by autogenous rib cartilage in auricular repair. The fabrication of the ear framework is a prolonged reconstructive procedure and depends of the surgeon's skill. In order to avoid these inconveniences and reduce surgery time, it was proposed in a previous work to use implants made with biocompatible materials. One of these is a scaffold made by fused deposition modeling using PLA based in the three-dimensional geometry of the ear cartilage. The aim of this work is to evaluate the feasibility of this scaffold to perform cell culture in a perfusion biorreactor by estimating the flow transport characteristics in porous media using a scaffold with the porous geometry of the human auricular cartilage for microtia. Flow and heat transfer through the scaffold were simulated by the lattice Boltzmann method, and permeability and shear stress distribution were obtained at different Reynolds numbers. The permeability values of the scaffold achieved are in the order of magnitude of scaffolds used for cell culture. Linear dependencies between maximum shear stress and Reynolds number, and between maximum shear stress and permeability were obtained. The values of shear stress achieved correspond to high percentage of cell viability. The scaffolds for microtia treatment with the proposed filling pattern select is appropriate for cell culture in a perfusion bioreactor with characteristics similar to those described herein.
\end{abstract}

Keywords: Microtia treatment; Lattice Boltzmann method; Perfusion biorreactor; Scaffold; Shear stress in porous media.

\section{Introduction}

The birth deformity of ear is known as microtia, which varies from a minimal deformed ear, known as grade 1, to the absence of auricular tissue or anotia. 1 The more frequent cases of microtia are grade 3 and these look "like a little sausage-shaped Wrinkle of skin"1. Microtia grade 2 looks like a miniature ear ${ }^{1}$.This malformation occurs once in every 6,000 births, 2 only one side is involved in 90 percent of the cases, and 63.1 percent of the patients are males and the other 36.9 percent are females ${ }^{2}$.

This malformation has been treated by reconstructing the external ear. In 1959, Tanzer made a successful reconstruction employing an autogenous rib cartilage as framework ${ }^{3}$. The use of autogenous rib cartilage in auricular repair has been used since that date and the results in a long term had reported ${ }^{4,5}$. The fabrication of the ear framework is a prolonged reconstructive procedure and depends of the surgeon's skill. In order to avoid these inconveniences and reduce surgery time, Berroteran 6 proposed to use implants made with biocompatible materials to treat microtia. One of these is a scaffold made by fused deposition modeling (FDM) using polylactic acid (PLA) based in the three-dimensional geometry of the ear cartilage. 6 This must have the appropriate conditions to develop a cell culture.

The objective of the present research is to evaluate the feasibility of a scaffold proposed in a previous work to perform cell culture in a biorreactor by estimating the flow transport characteristics in porous media using a scaffold with the porous geometry of the human auricular cartilage for microtia. The micro-fluid dynamics through a scaffold is simulated by three-dimensional lattice Boltzmann method. The characteristic properties in porous media are the Darcy permeability and the shear stress distribution, because the feasibility of a specific scaffold to perform in vitro cell culture could be set knowing these characteristic properties.

One of the scopes of previous research works is to evaluate charac- teristic properties of fluid flow in porous media of the employed scaffold by computational fluid dynamics. Some of these works simulated flow in a geometry of the employed scaffold obtained by microtomography, ${ }^{7-13}$ and when the geometry of the scaffold is built by three-dimensional printing, the model used in the simulations is draw using of the same parameters of the printing. ${ }^{14-16}$ For this application the flow field has been modeled by the finite volume method, $8,9,14,17$ the finite element method, $15,16,18$ and the lattice Boltzmann method $\mathrm{d}^{7,8,10-13,19}$ with results similar to experimental data, however not precise to these. Pennella et al. ${ }^{13}$ explain some causes of the difference between the permeability values obtained experimentally and those calculated by computational fluid dynamic among which are the reconstructed scaffold volumes are in different orders of magnitude than the experimental samples and the resolution of the microtomography images used to reconstruct the three-dimensional models is not adequate. These previous publications differ in the way that they model the flow through the porous media and in the characteristic properties due to the specific objectives of each research. For example, Ferroni et al. ${ }^{20}$ in addition to simulate flow through the porous scaffold, they also studied the oxygen consumption in this, and Alam et al. ${ }^{14}$ present a tool to simulate cell growth in bone tissue. Table 1 shows details about each referenced work.

The shear stress produced by the flow at the internal walls of the scaffold has been studied due to shear stress is an important regulator in cell function ${ }^{7}$. Croughan and Wang ${ }^{21}$ describe the shear stress effects on metabolism of living animal cells in bioreactors, and Liu, et al. ${ }^{22}$ demonstrated that shear stress induced by laminar flow can promote autophagy in vascular endothelial cells. According to its magnitude, shear stress could have a beneficial effect on cell growth ${ }^{23}$, can damage cells ${ }^{24}$ or prevents attachment of the cells to the scaffold ${ }^{15,16}$. Computational fluid dynamics have been employed to obtain shear stress values in scaffolds concluding that shear stress is a function of the porous geometry and flow regime ${ }^{15}$,

\footnotetext{
${ }^{1}$ Departamento Tecnología Industrial, Universidad Simón Bolívar, Camurí Grande Valley, Naiguatá, 1160, Venezuela.

2 Departamento de Mecánica, Universidad Simón Bolívar. AP 89000, Caracas, Venezuela.

${ }^{3}$ Grupo de Biomecánica, Universidad Simón Bolívar. AP 89000, Caracas, Venezuela.

${ }^{4}$ Grupo B5IDA, Departamento de Química, Universidad Simón Bolívar. AP 89000, Caracas, Venezuela.
} 


\begin{tabular}{|c|c|c|c|c|}
\hline Reference & Method & Details about method & Flow conditions & Porous geometry \\
\hline $\begin{array}{l}\text { Porter et al. } \\
(2005) 7\end{array}$ & $\begin{array}{l}\text { Lattice Boltzmann } \\
\text { method }\end{array}$ & $\begin{array}{l}\text { Lattice Boltzmann } \\
\text { method, BGK, D3Q15 } \\
\text { lattice }\end{array}$ & $0.15<\operatorname{Re}<0.9$, Darcy flow & $\begin{array}{l}\text { Porous scaffolds imaged via } \\
\text { micro-CT of human trabecular } \\
\text { bone }\end{array}$ \\
\hline $\begin{array}{l}\text { Boschetti et al. } \\
\text { (2006)15 }\end{array}$ & $\begin{array}{l}\text { Finite element } \\
\text { method }\end{array}$ & $\begin{array}{l}\text { FIDAP (Fluent Inc) for } \\
\text { finite element method }\end{array}$ & $\begin{array}{l}\text { Velocity }=689,338,163 \text {, and } \\
105 \mathrm{~mm} / \mathrm{s} \\
\text { Density }=1000 \mathrm{~kg} / \mathrm{m} 3 \\
\text { Viscosity }=8.2 \times 104 \mathrm{~kg} /(\mathrm{m} \cdot \mathrm{s}) \\
\operatorname{Re}=3.97 \text { and } 5.37 \times 103\end{array}$ & $\begin{array}{l}\text { Microporous polymeric scaffold } \\
\text { (Degrapol }{ }^{\circledR} \text { ) by micro-compu- } \\
\text { ted tomography }\end{array}$ \\
\hline $\begin{array}{l}\text { Cioffi et al. } \\
(2006 a) 8\end{array}$ & $\begin{array}{l}\text { Finite element } \\
\text { method }\end{array}$ & $\begin{array}{l}\text { Fluent for finite volume } \\
\text { method }\end{array}$ & $\begin{array}{l}\text { Velocity }=0.000053 \mathrm{~m} / \mathrm{s}, \\
\text { Density }=1000 \mathrm{~kg} / \mathrm{m} 3 \text {, Vis- } \\
\text { cosity }=8.1 \times 104 \mathrm{~Pa} \mathrm{~s}, \\
\mathrm{Re}=3.42 \times 104,3.71 \times 104, \\
\text { and } 3.70 \times 104\end{array}$ & $\begin{array}{l}\text { Microporous polymeric scaffold } \\
\text { (Degrapol }{ }^{\circledR} \text { ) by micro-compu- } \\
\text { ted tomography }\end{array}$ \\
\hline $\begin{array}{l}\text { Cioffi et al. } \\
\text { (2006b)8 }\end{array}$ & $\begin{array}{l}\text { Finite volume } \\
\text { method and lat- } \\
\text { tice Boltzmann } \\
\text { method }\end{array}$ & $\begin{array}{l}\text { Fluent for finite volume } \\
\text { method and Lattice } \\
\text { Boltzmann method }\end{array}$ & $\begin{array}{l}\text { Volumetric flow rate }=0.5 \\
\mathrm{~cm} 3 / \mathrm{min} \text { through a } 15 \mathrm{~mm} \\
\text { diameter scaffold }\end{array}$ & $\begin{array}{l}\text { Microporous polymeric scaffold } \\
\text { (Degrapol }{ }^{\circledR} \text { ) by micro-compu- } \\
\text { ted tomography }\end{array}$ \\
\hline \multirow[t]{2}{*}{$\begin{array}{l}\text { Zeiser et al. } \\
\text { (2008)10and a lattice } \\
\text { Boltzmann method } \\
\text { (LBM }\end{array}$} & \multirow[t]{2}{*}{$\begin{array}{l}\text { Lattice Boltzmann } \\
\text { method }\end{array}$} & $\begin{array}{l}\text { Lattice Boltzmann } \\
\text { method, BGK, D3Q19 } \\
\text { lattice }\end{array}$ & $\begin{array}{l}\text { Velocity }=1 \mathrm{~mm} / \mathrm{s} \\
\text { Density }=1200 \mathrm{~kg} / \mathrm{m} 3 \text {, Visco- } \\
\text { sity }=500 \text { to } 2000 \mathrm{~Pa} \text { S, } \\
\mathrm{Re}=10-6 \text { for vertebroplasty } \\
\text { application }\end{array}$ & \multirow[t]{2}{*}{$\begin{array}{l}\text { Pore-scale structure by seg- } \\
\text { ment X-ray microcomputed } \\
\text { tomography of bone }\end{array}$} \\
\hline & & & $\begin{array}{l}\text { Characteristic length of the } \\
\text { trabecular bone }=1 \mathrm{~mm} \text {, }\end{array}$ & \\
\hline \multirow{2}{*}{$\begin{array}{l}\text { Vossenberg et al. } \\
\text { (2009)16 }\end{array}$} & \multirow{2}{*}{$\begin{array}{l}\text { Finite element } \\
\text { method }\end{array}$} & COMSUL & \multirow[t]{2}{*}{$\mathrm{Re}=7.5 \times 10-3$} & \multirow{2}{*}{$\begin{array}{l}\text { Printed regular scaffolds with } \\
\text { fiber radius equal to } 75 \mu \mathrm{m}\end{array}$} \\
\hline & & Multiphysics 3.3 & & \\
\hline $\begin{array}{l}\text { Voronov et al. } \\
\text { (2010)11 }\end{array}$ & $\begin{array}{l}\text { Lattice Boltzmann } \\
\text { method }\end{array}$ & $\begin{array}{l}\text { Lattice Boltzmann } \\
\text { method, BGK, D3Q15 } \\
\text { lattice }\end{array}$ & Velocity $=0.0044 \mathrm{~cm} / \mathrm{s}$ & $\begin{array}{l}\text { Porous scaffolds imaged via } \\
\text { micro-CT of a salt grain }\end{array}$ \\
\hline $\begin{array}{l}\text { Pennella et al. } \\
(2013) 13\end{array}$ & $\begin{array}{l}\text { Lattice Boltzmann } \\
\text { method }\end{array}$ & $\begin{array}{l}\text { Palabos for lattice } \\
\text { Boltzmann method, } \\
\text { BGK, D3Q19 lattice, }\end{array}$ & $\mathrm{Re}<<1$ & $\begin{array}{l}\text { Porous scaffolds imaged via } \\
\text { micro-CT }\end{array}$ \\
\hline Alam et al. (2016)14 & $\begin{array}{l}\text { lattice Boltzmann } \\
\text { method }\end{array}$ & $\begin{array}{l}\text { Lattice Boltzmann } \\
\text { method, BGK, D3Q15 } \\
\text { lattice }\end{array}$ & No show & $\begin{array}{l}\text { Porous scaffolds imaged via } \\
\text { micro-CT }\end{array}$ \\
\hline Ferroni et al. (2016)20 & $\begin{array}{l}\text { Finite element } \\
\text { method }\end{array}$ & $\begin{array}{l}\text { Comsol Multiphysics } \\
4.3 b \text { for two-dimen- } \\
\text { sional and three-di- } \\
\text { mensional flow simu- } \\
\text { lations }\end{array}$ & $\begin{array}{l}\text { Density }=1029 \mathrm{~kg} / \mathrm{m} 3, \\
\text { Viscosity }=0.0012 \mathrm{~kg} /(\mathrm{m} \cdot \mathrm{s}) \\
\operatorname{Re}=2 \times 105\end{array}$ & $\begin{array}{l}\text { Idealized geometry - printed } \\
\text { scaffolds }\end{array}$ \\
\hline Malvè et al (2018)18 & $\begin{array}{l}\text { Finite element } \\
\text { method }\end{array}$ & Adina R\&D & $\begin{array}{l}\text { Density }=1000 \mathrm{~kg} / \mathrm{m} 3 \\
\text { Viscosity }=0.00001 \mathrm{~kg} /(\mathrm{m} \cdot \mathrm{s})\end{array}$ & $\begin{array}{l}\text { Idealized geometry - printed } \\
\text { scaffolds }\end{array}$ \\
\hline Ali et al. (2020)17 & $\begin{array}{l}\text { Finite volume } \\
\text { method }\end{array}$ & Ansys Fluent software & $\begin{array}{l}\text { Velocity }=0.1 \mathrm{~mm} / \mathrm{s}, \\
\text { Density }=1000 \mathrm{~kg} / \mathrm{m} 3, \\
\text { Viscosity }=0.0037 \mathrm{~kg} /(\mathrm{m} \cdot \mathrm{s})\end{array}$ & $\begin{array}{l}\text { Eight idealized geometries - } \\
\text { printed scaffolds }\end{array}$ \\
\hline
\end{tabular}

Table 1 - Computational fluid dynamic methods, flow conditions, and porous geometry employed in each referenced work. 


\section{Boschetti et al.}

and more specific of the Darcy permeability coefficient ${ }^{16}$.

Generally, cell cultures are performed at constant temperature around 37 degrees Celsius, the initial conditions are at room temperature (around 21 degrees Celsius). Schuerlein et al. ${ }^{25}$ report a variation of temperature in the medium in tissue chamber from initially 21 to 36 degrees Celsius within $60 \mathrm{~min}$ in a perfusion bioreactor. These temperature variations could change the flow properties in the scaffold and are studied herein.

The lattice Boltzmann method has been very useful to solve flow in porous media because of it avoids to create an intricate mesh in this media, required by other computational fluid dynamic methods, besides this method allows multi-physics applications like flow and heat transfer. In this case, the open access code Palabos ${ }^{26}$, based in this method, is chosen to perform the simulations. This code is capable of modeling three-dimensional, unsteady, low Reynolds flow.

\section{Methodology Geometry employed}

Berroteran 6 built six different samples of scaffolds with the geometry of the human auricular cartilage by fused deposition modeling (FDM) using a thread of polylactic acid (PLA) fibers. These samples differ in orientation (horizontal, vertical, and lateral), fill pattern (honeycomb, line, and rectilinear), layer thickness, and fill density. To print these scaffolds was used
FDM machine brand RepRapBCN ${ }^{\circledR}$, Esun 3D filament PLA as building material (Esun 3D filament PVA as support material). Two of these scaffolds were selected and reported an average pore size between 200 and 500 $\mu \mathrm{m}$, which is considered appropriate for the adequate cellular proliferation in the scaffold according to Wu et al..$^{27}$ and Sobral et al. ${ }^{28}$ These two scaffolds were printed with orientation and fill pattern horizontal honeycomb and lateral rectilinear, layer size of 0.4 and $0.2 \mathrm{~mm}$, respectively, and both with a fill density of $60 \%$. The resultant average pore sizes are $471 \pm 19$ and $487 \pm 36 \mu \mathrm{m}$, respectively.

Using the data of the scaffold printed with orientation lateral and fill pattern rectilinear, a digital geometry with the same orientation and fill pattern, layer size of $0.2 \mathrm{~mm}$ and pore size $487 \pm 36 \mu \mathrm{m}$ was created in order to simulate fluid flow in a small sample of the complete scaffold geometry. Figure 1 presents photographs of this scaffold. The digital geometry of the test scaffold has twelve layers of depth, due to this is the maximum resultant number of layers depth of the printed scaffold of the human auricular cartilage at its thickest point. Its dimensions are height 4.925 $\mathrm{mm}$, width $5.225 \mathrm{~mm}$ and length $2.675 \mathrm{~mm}$. The geometry was drawn using the design program Rhinoceros ${ }^{29}$ joint with the plugin Intralattice ${ }^{30}$, which allows generating solid lattice structures by an algorithm. Figure 2 presents the geometry achieved with has layer size of $0.2 \mathrm{~mm}$ and pore size of $483.379 \mu \mathrm{m}$.
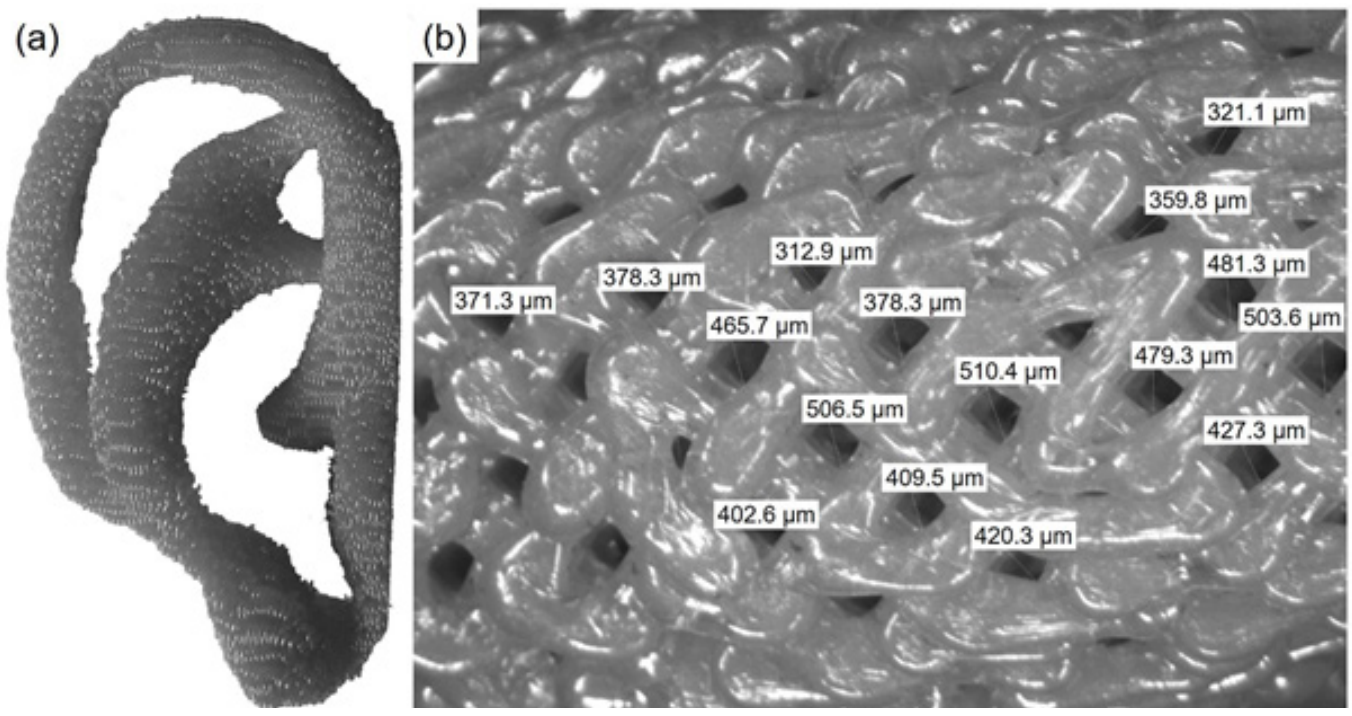

Figure 1 - Test scaffold printed with PLA using FDM fill pattern rectilinear, orientation lateral, layer size of $0.2 \mathrm{~mm}$ and pore size $487 \pm 36 \mu \mathrm{m}$, (a) complete and (b) zoom .

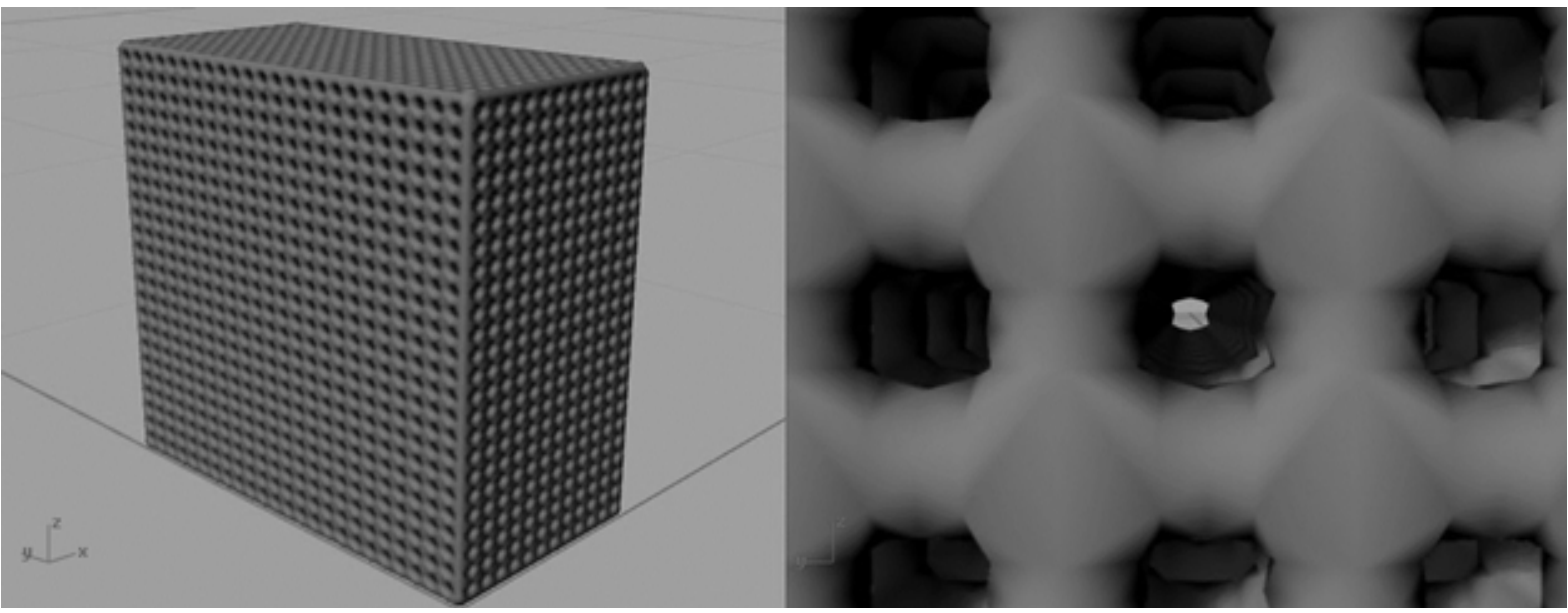

Figure 2 - Scaffold created to perform computational fluid dynamic tests (left) and detail of the fill pattern (right). 
Flow simulation by lattice-Boltzmann method Bhatnagar-Gross-Krook scheme

The evolution of particle distribution functions $f_{i}(\vec{x}, t, \vec{V})$ is specified by the Boltzmann equation, which is expressed as a function of the collision operator $\Omega: 31$

$$
\frac{\partial f}{\partial t}+\vec{V} \cdot \nabla f=\Omega
$$

The collision operator describes the interactions of particles on micro scale. Equation (1) is discretized by the dire extifonalparticle velocities $\left(\vec{e}_{i}\right)$ and in space and time (c= $\left.=\Delta \mathrm{x} / \Delta t\right)$, to obtain the lattice Boltzmann equation with the Bhatnagar-Gross-Krook (BGK) collision operator considering the dimensionless relaxation time related to mass transfer $\left(\tau_{m}\right)^{31}$,

$$
f_{i}\left(\vec{x}+\vec{e}_{i} \Delta t, t+\Delta t\right)-f_{i}(\vec{x}, t)=-\frac{1}{\tau_{m}}\left[f_{i}(\vec{x}, t)-f_{i}^{e q}(\vec{x}, t)\right]
$$

The equilibrium distribution function ${ }^{31,32}$

$$
f_{i}^{q}(\vec{x}, t)=\rho w_{i}\left[1+\frac{\vec{e}_{i} \cdot \vec{V}}{c_{s}^{2}}+\frac{\left(\vec{e}_{i} \cdot \vec{V}\right)^{2}}{2 c_{s}^{4}}-\frac{(\vec{V})^{2}}{2 c_{s}^{2}}\right]
$$

Where density is $\rho$, the macroscopic velocity is $\vec{V}$ and the pseudo sound speed $c_{s}$, which is defined as $c_{s}=\sqrt{ } 1 / 3 c$.

The particle distribution function for advection and diffusion ( $\left.g_{i}^{e q}\right)$ of a scalar field of temperature $T$ is expressed as in function of dimensionless relaxation time related to heat transfer $(4)^{32}$

$$
g_{i}\left(\vec{x}+\vec{e}_{i} \Delta t, t+\Delta t\right)-g_{i}(\vec{x}, t)=-\frac{1}{\tau}\left[g_{i}(\vec{x}, t)-g_{i}^{e q}(\vec{x}, t)\right]
$$

The linear form of the equilibrium distribution function for this case is ${ }^{32}$

$$
g_{i}^{e q}(\vec{x}, t)=T \cdot w_{i}\left[1+\frac{\vec{e}_{i} \cdot \vec{V}}{c_{s}^{2}}\right]
$$

For three-dimensional lattices with nineteen discrete velocities (D3Q19), the weight factors are $w 0=0, w i=1 / 18$ for $i=1-6$, $w i=1 / 36$ for $i=7-18.31$ The macroscopic density, velocity and temperature are calculated in each node of the lattice when is consider mass, momentum, and energy conservation, respectively32.

$$
\begin{aligned}
& \sum_{i=0}^{i} f_{i}=\rho \\
& \sum_{i=0}^{i} f_{i} \vec{e}_{i}=\rho \vec{V} \\
& \sum_{i=0}^{i} g_{i}=T
\end{aligned}
$$

The kinematic viscosity $(\mu)$ and thermal diffusivity $(\alpha)$ are expressed as a function of lattice units, respectively:32

$$
\begin{gathered}
v=c_{s}^{2}\left(\tau_{m}-0.5\right) \frac{\Delta x^{2}}{\Delta t} \\
\alpha=c_{s}^{2}\left(\tau_{s}-0.5\right) \frac{\Delta x^{2}}{\Delta t}
\end{gathered}
$$

The relation between kinematic viscosity and thermal diffusivity is known as Prandtl number (Pr).

\section{Fluid flow in porous media}

The Darcy flow transport model describes the fluid flow through a porous media. For Reynolds numbers lower than 10 the permeability is estimated by the volumetric flow rate $(Q)$ and the pressure drop through the porous media $(\Delta P): 13,33$

$$
k=\frac{\mu}{\Delta P} L\left(\frac{Q}{A}\right)
$$

Where $\mu$ is the dynamic viscosity, $L$ and $A$ are the thickness of the sample in the direction of the flow and the surface area of the scaffold to flow, respectively.

The Reynolds number is calculated based in:

$$
R=\frac{\rho u_{0} D_{h}}{\mu}=\frac{u_{0} D_{h}}{v}
$$

Where $\rho$ is the fluid density, $v$ is the kinematic viscosity, $D h$ is the hydraulic diameter, and knowing that the velocity is $u_{0}=Q / A$.

Cioffi et al. ${ }^{8}$ present an analytical equation to link permeability with average shear stress,

$$
\bar{\tau}=\frac{\mu \cdot u_{0}}{\sqrt{k}}
$$

\section{Simulation conditions}

The flow conditions were set to model a perfusion bioreactor and the respective domain of the simulation is shown in Figure 3, which are used to force culture medium through the pores of three-dimensional scaffolds. Perfusion bioreactors improve cartilage-like matrix synthesis for chondrocytes and chondrocyte growth ${ }^{34}$. The flow simulations through test scaffold shown in Figure 2 were carried out by Palabos ${ }^{26}$ using D3Q19 lattice model and BGK scheme because of the Reynolds numbers in perfusion bioreactor are low. A duct of rectangular section with walls with periodic boundary condition (in order to reduce the computational cost to model wall without friction) due to the wall effect can be considered negligible ${ }^{16}$, scaffold geometry with bounce-back boundary condition for no-slip condition, inlet flow with constant and uniform velocity in the $x$-axis, and outlet flow condition with constant pressure. The dimensions of the lattice $\mathrm{N}_{\mathrm{x}}, \mathrm{N}_{\mathrm{y}}$ and $\mathrm{Nz}$ are $443,80 \mathrm{y} 77$, respectively, for a total of 2.72888 million of elements.

Table 2 presents the parameters employed in the simulations. The values of viscosity and density of the culture medium were taken from Ferroni et al. ${ }^{20}$, and the Prandtl number was set equal to the water. It was selected a group Reynolds numbers of low value and using these the corresponding inlet velocity for each case is estimated. In order to achieve these Reynolds numbers in the simulations and so that the solutions accomplish a convergence, the inlet velocity, the kinematic viscosity, and the velocity in lattice units are placed to achieve a value of dimensionless relaxation time close but not equal to 0.5 . The resultant dimensionless relaxion time for each simulation results equal to 0.503570457 and 0.500522803 for flow and heat transfer, respectively. 


\section{Boschetti et al.}

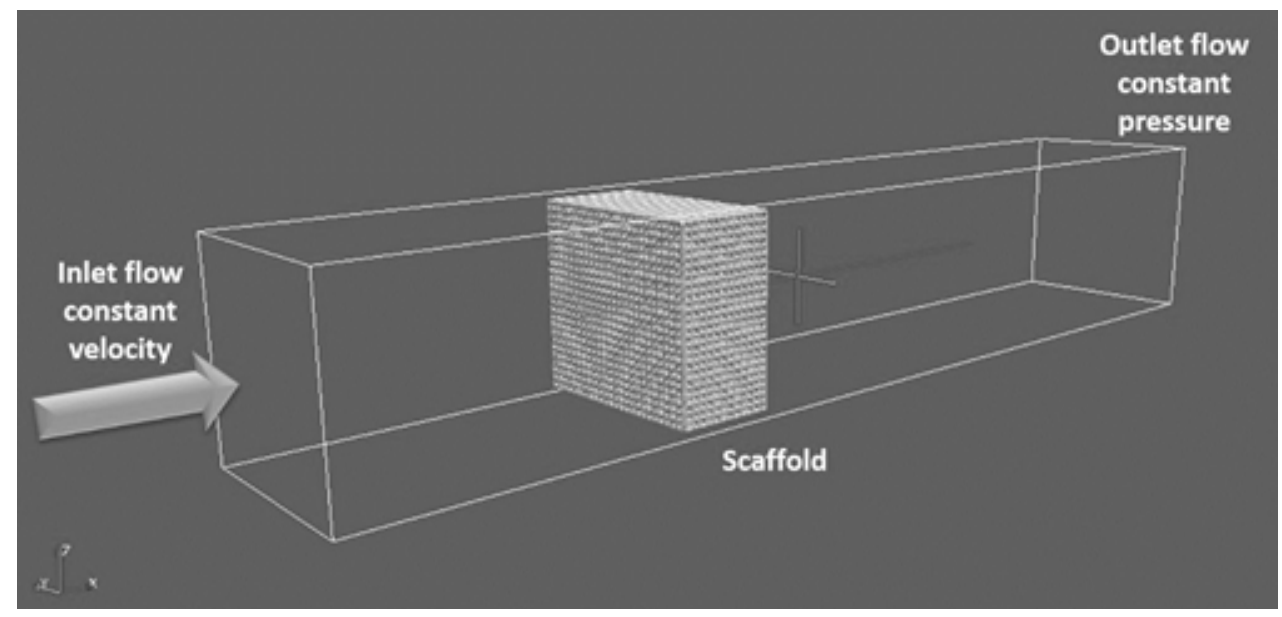

Figure 3 - Domain of the simulation.

\begin{tabular}{|c|c|c|}
\hline Parameter & Description & Value \\
\hline$D_{h}$ & hydraulic diameter of the scaffold & $0.00437356112 \mathrm{~m}$ \\
\hline$\mu$ & Viscosity of the culture medium & $0.0012 \mathrm{~g} /(\mathrm{m} \cdot \mathrm{s})$ \\
\hline$\rho$ & Density of the culture medium & $1029 \mathrm{~kg} / \mathrm{m}^{3}$ \\
\hline V & Kinematic viscosity & $1.17 \times 10^{-6} \mathrm{~m}^{2} / \mathrm{s}$ \\
\hline $\operatorname{Pr}$ & Prandtl number & 7 \\
\hline
\end{tabular}

Table 2 - Values employed in the simulations.

\section{Results and Discussion}

The lattice Boltzmann method is highly parallelizable which allows using many cores of a central processing unit (CPU). In this case, using the entire cores of a desktop with a processor Intel ${ }^{\circledR}$ Core $^{\mathrm{TM}}$ i5-7400 of RAM 8 GBytes each simulation achieved convergence for average energy lower than $10^{-6}$ of error at $8 \mathrm{~h} 15 \mathrm{~min}$ for isothermal cases (32292 iterations, $52.577 \mathrm{~s}$ of lattice time) and $20 \mathrm{~h} 21 \mathrm{~min}$ for flow and heat transfer cases (81480 iterations, 129.427 s of lattice time). During simulations, Palabos printed vti files every $2 \mathrm{~s}$ of lattice time which contain velocity, pressure and temperature field of the fluid flow in lattice units. Paraview was used to obtain velocity, pressure, and shear stress in physical units.

Figures 4 and 5 show the scaffold permeability and shear stress, respectively, as a function of Reynolds number. The shear stress $(\mu \times \nabla \vec{V})$ was calculated using the data obtained from each simulation. It is observed that at different Reynolds numbers the permeability values are close between them for $\operatorname{Re} \leq 0.2$, and these are in the order of magnitude of bone and cartilage scaffolds compiled by Pennella et al. 13 Figure 5 shows that the shear stress values into the scaffold as a function of Reynolds number increase linearly described by Eq. (14),

$$
\tau_{\max }=4.98057 \times 10^{5} R e
$$

which can be used to adjust the flow velocity or volumetric flow rate to a desired maximum shear stress. The values of average shear stress from Eq. (13) are higher than those ones obtained from simulation. Cioffi et al. ${ }^{8}$ reported a similar difference between the values calculated by numerical simulation and the estimated by Eq. (13). The values of shear stress obtained correspond to high percentage of cell viability according to values reported by Nair et al. ${ }^{24}$ Figure 6 illustrates that the relation between the measured maximum shear stress and the permeability for the geometry presented herein achieves a linear function represented by Eq. (15). This relation only applies for this specific geometry in this range of permeability values.

$$
\tau_{\max }=-5.06865 \times 10^{6} k+5.61111 \times 10^{-3}
$$

The influence of the difference of the temperature between the culture medium and the scaffold in the permeability and maximum shear stress is evaluated varying the temperature of the scaffold wall from 20 to 40 degrees Celsius respect to the culture medium at 30 degrees Celsius (303.15 $\mathrm{K})$. The maximum difference attained for permeability is 0.03871 percent and for shear stress is 0.03369 percent when the object wall is equal to 35 degrees Celsius. This indicate that the small variations in temperature that may occur in the bioreactor do not affect largely the conditions in the culture medium.

Figures 7 and 8 present pressure, velocity magnitude, and shear stress along ( $\mathrm{x}$-axis) in the middle and wide ( $\mathrm{z}$-axis) between the first two layers 
of the scaffold geometry, respectively, at $\mathrm{Re}=4.374 \times 10-5$. It is observed along $x$-axis that the velocity initially increases, and then slight falls of this when going through the scaffold, a characteristic pressure drop in flow through porous media, and that the shear stress is highest between the first two layers of the scaffold along $x$-axis direction. Figure 8 shows that the pressure varies between layers of the geometry in a regular way, however the velocity magnitude is larger in the center of the geometry in almost symmetrical distribution, and the shear stress present a non-regular distribution. Nevertheless, shear stress profiles in regular scaffolds obtained by Vossenberg et al.16 and Hossain, Bergstrom, and Chen23 have regular distribution. This difference may be due in these two previous mentions works, flow field is simulated through small geometries of two and five layers along z-axis, respectively, and in the geometry present herein have twenty-four, representing a larger domain where the flow field could develop in other way.

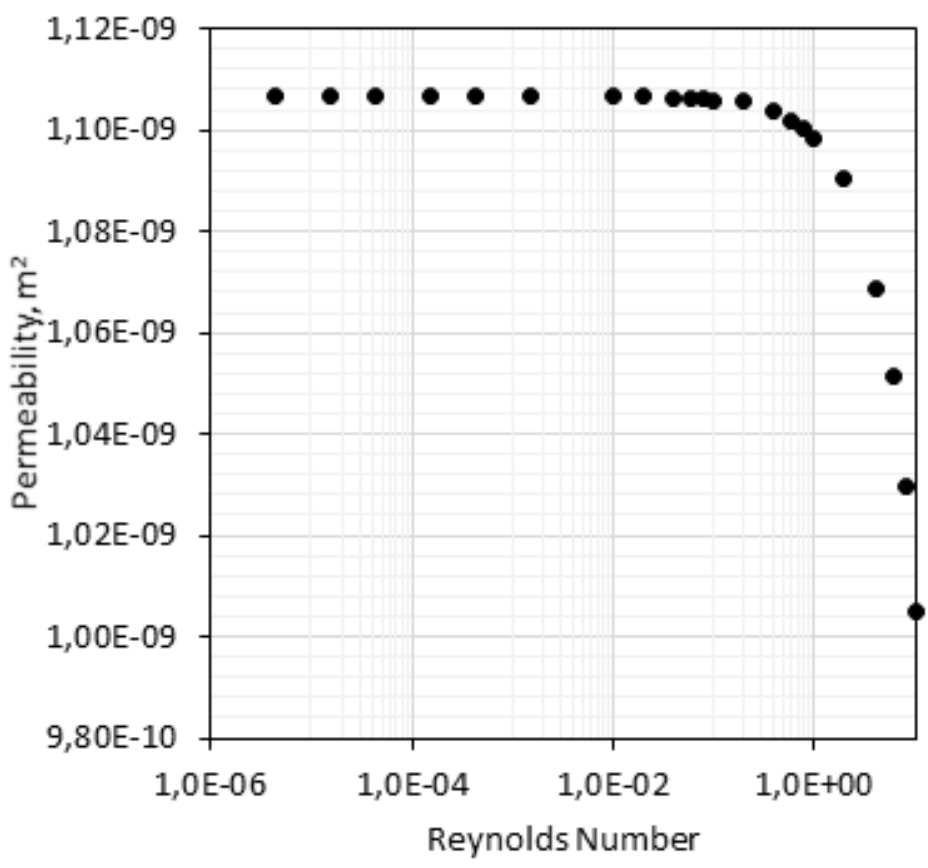

Figure 4 - Achieved scaffold permeability as a function of Reynolds number.

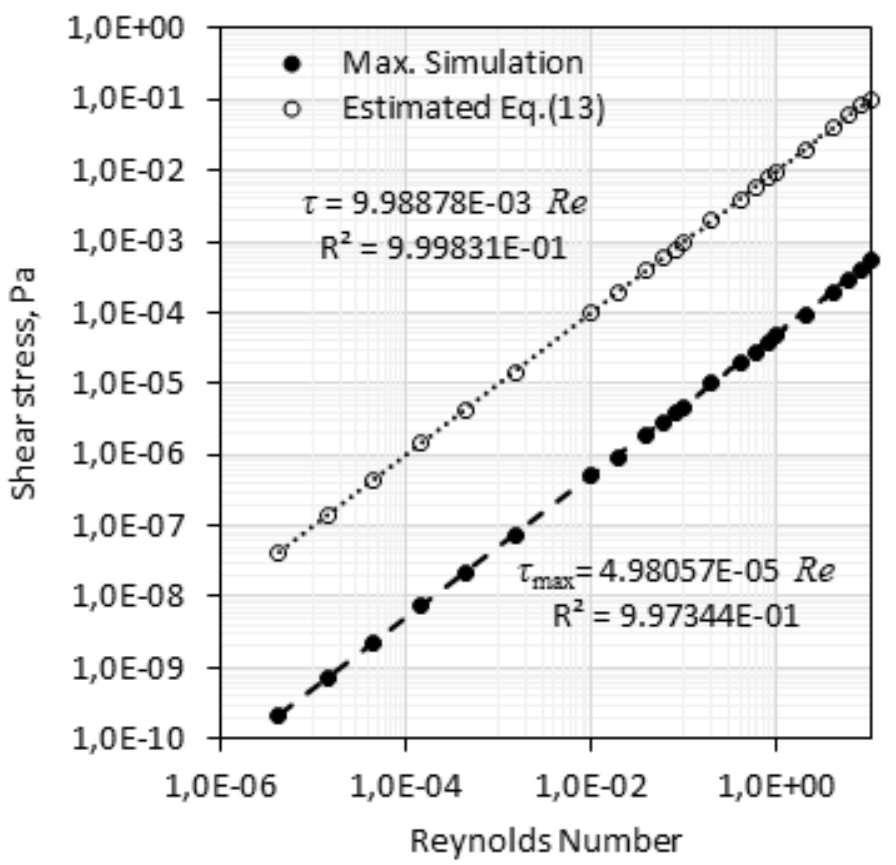

Figure $\mathbf{5}$ - Shear stress as a function of Reynolds number. 


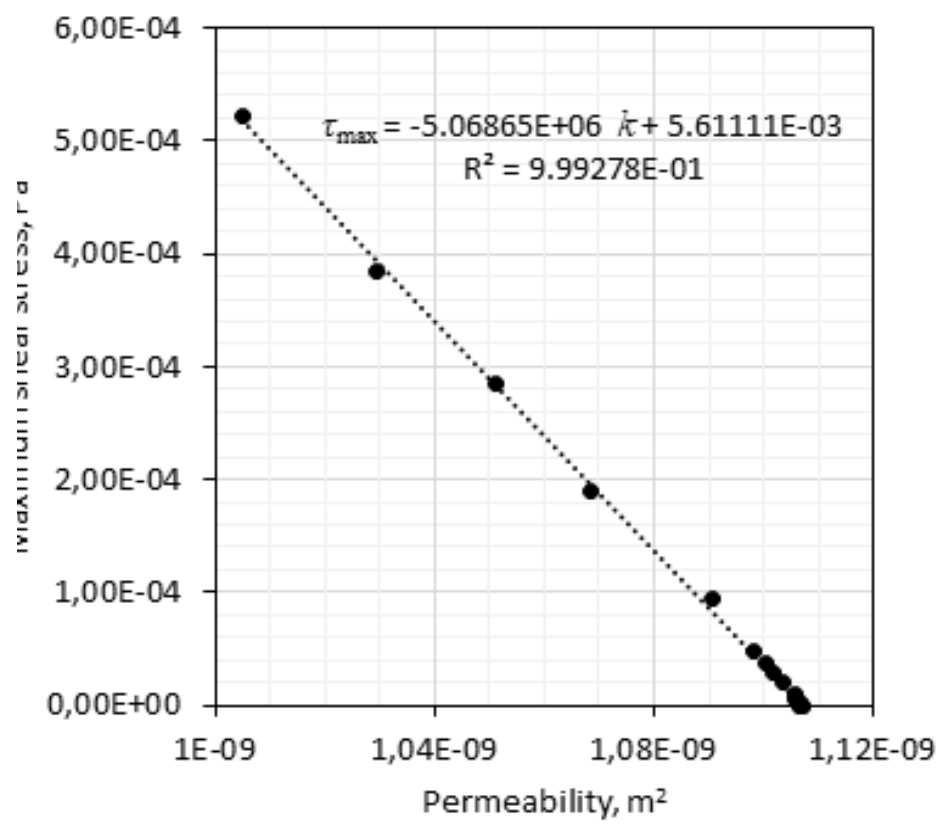

Figure 6 - Maximum shear stress as a function of scaffold permeability.
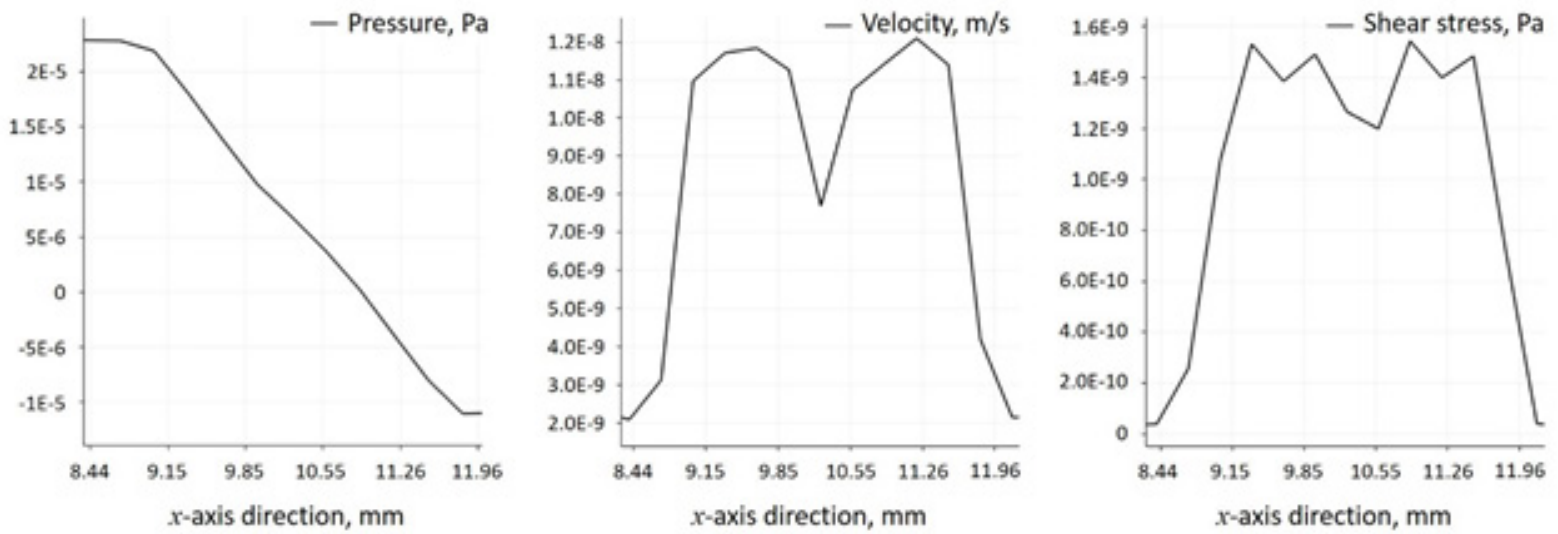

Figure 7 - Pressure, velocity magnitude, and shear stress in $x$-axis direction of the scaffold at Reynolds number equal to $4.374 \times 10^{-5}$.
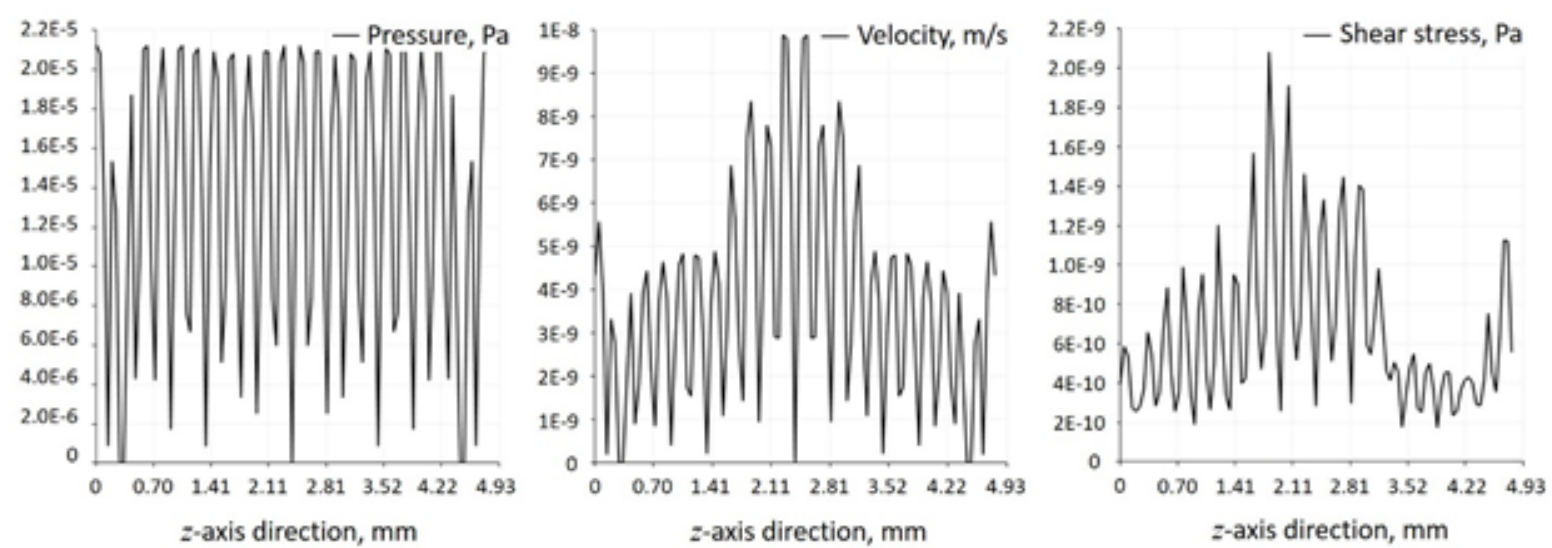

Figure 8 - Pressure, velocity magnitude, and shear stress in z-axis direction of the scaffold at Reynolds number equal to $4.374 \times 10^{-5}$ 


\section{Conclusions}

The flow through a test piece based on the scaffold of the human auricular cartilage for microtia proposed for cell culture in a perfusion biorreactor was simulated using the Lattice Boltzmann method to evaluate the flow transport characteristics in a porous media. It was determined that the permeability of the scaffold is in the order of magnitude of scaffold used for cell culture, and the possible variations of temperature in the tissue chamber do not affect significantly permeability and shear stress values. Linear dependences between maximum shear stress and Reynolds number, and maximum shear stress and permeability, respectively, were found. The values of shear stress achieved correspond to high percentage of cell viability. Based on the results obtained, it can be concluded that the scaffolds for microtia treatment with the proposed filling pattern select is appropriate for cell culture in a perfusion bioreactor with characteristics similar to those described in this work.

\section{Acknowledgements}

Authors wants to thank to Dean of Research and Development, Simon Bolivar University at Caracas, Venezuela for the financial support.

Conflict of interest statement

There is not conflict of interest.

\section{References}

1. Brent B. What is microtia? Microtia-Atresia, http://www.microtia. us.com/ (2011).

2. Aase JM, Tegtmeier RE. Microtia in New Mexico: Evidence for multifactorial causation. Birth Defects Orig Artic Ser 13: 113-6 (1977).

3. Tanzer RC. Total Reconstruction of the External Ear. Plast Reconstr Surg Transplant Bull 23: 1-15 (1959).

4. Tanzer RC. Microtia - a Long-Term Follow-Up of 44 Reconstructed Auricles. Plast Reconstr Surg 61: 161-166 (1978). https://doi. org/10.1097/00006534-197802000-00001.

5. Brent B. Auricular Repair with Autogenous Rib Cartilage Grafts: Two Decades of Experience with 600 Cases. Plast Reconstr Surg $\mathbf{9 0}$ 355-374 (1992).

6. Berroterán MV. Implantes de Microtia Fabricados con Manufactura Aditiva Usando Polímeros Biocompatibles e Hidrogeles Moldeados. Master Thesis. Universidad Simón Bolívar (2015).

7. Porter B, Zauel R, Stockman H, Guldberg, R, Fyhrie, D. 3-D computational modeling of media flow through scaffolds in a perfusion bioreactor. J Biomech 38: 543-549 (2005). https://doi.org/10.1016/j. jbiomech.2004.04.011.

8. Cioffi M, Boschetti F, Raimondi MT, Dubini, G. Modeling evaluation of the fluid-dynamic microenvironment in tissue-engineered constructs: A micro-CT based model. Biotechnol Bioeng 93: 500-510 (2006). https://doi.org/10.1002/bit.20740.

9. Cioffi M, Galbusera F, Raimondi MT, Dubini, G. Computational modelling of microfluidynamics in bioreactor-cultured cellular constructs. J Biomech 39: S225 (2006). https://doi.org/10.1016/ S0021-9290(06)83831-5.

10. Zeiser T, Bashoor-Zadeh M, Darabi A, Baroud G. Pore-scale analysis of Newtonian flow in the explicit geometry of vertebral trabecular bones using lattice Boltzmann simulation. Proc Inst Mech Eng Part H J Eng Med 222: 185-194 (2008). https://doi.org/10.1243/ 09544119JEIM261.
11. Voronov R, VanGordon S, Sikavitsas VI, Papavassiliou, DV. Computational modeling of flow-induced shear stresses within 3D salt-leached porous scaffolds imaged via micro-CT. J Biomech 43: 1279-1286 (2010). https://doi.org/10.1016/j.jbiomech.2010.01.007.

12. Pennella F, Cerino G, Massai D, Gallo D, Falvo D'Urso Labate G, Schiavi A, Deriu, MA, Audenino, A, and Morbiducci, UA. A Survey of Methods for the Evaluation of Tissue Engineering Scaffold Permeability. Ann Biomed Eng 41: 2027-2041 (2013). https://doi. org/10.1007/s10439-013-0815-5.

13. Pennella F, Gentile P, Deriu MA, Gallo, D, Schiavi, A, Ciardelli, G, Lorenz, E, Hoekstra, AG, Audenino, A, and Morbiducci, U. A Virtual Test Bench to Study Transport Phenomena in 3D Porous Scaffolds Using Lattice Boltzmann Simulations. SBC2013-14489. In: ASME 2013 Summer Bioengineering Conference, Sunriver, Oregon, p. V01AT07A020 (2013). https://doi.org/10.1115/SBC2013-14489.

14. Alam TA, Pham QL, Sikavitsas VI, Papavassiliou D V., Shambaugh RL, Voronov RS. Image-based modeling: A novel tool for realistic simulations of artificial bone cultures. Technology 04: 229-233 (2016). https://doi.org/10.1142/S233954781620003X.

15. Boschetti F, Raimondi MT, Migliavacca F, Dubini, G. Prediction of the micro-fluid dynamic environment imposed to three-dimensional engineered cell systems in bioreactors. J Biomech 2006; 39 : 418-425.

16. Vossenberg, P, Higuera, GA, van Straten, G, van Blitterswijk, CA, van Boxtel, AJB. Darcian permeability constant as indicator for shear stresses in regular scaffold systems for tissue engineering. Biomech Model Mechanobiol 8: 499-507 (2009). https://doi.org/10.1007/ s10237-009-0153-6.

17. Ali D, Ozalp M, Blanquer SBG, Onel, S. Permeability and fluid flow-induced wall shear stress in bone scaffolds with TPMS and lattice architectures: A CFD analysis. Eur J Mech - B/Fluids 79: 376-385 (2020). https://doi.org/10.1016/j.euromechflu.2019.09.015

18. Malvè $M$, Bergstrom DJ, Chen XB. Modeling the flow and mass transport in a mechanically stimulated parametric porous scaffold under fluid-structure interaction approach. Int Commun Heat Mass Transf 96: 53-60 (2018). https://doi.org/10.1016/j.icheatmasstransfer.2018.05.014

19. Hossain MS, Chen XB, Bergstrom DJ. Fluid flow and mass transfer over circular strands using the lattice Boltzmann method. Heat Mass Transf 51: 1493-1504 (2015). https://doi.org/10.1007/s00231-015$1514-6$.

20. Ferroni M, Giusti S, Nascimento D, Silva A, Boschetti F, Ahluwalia A. Modeling the fluid-dynamics and oxygen consumption in a porous scaffold stimulated by cyclic squeeze pressure. Med Eng Phys 38: 725-732 (2016). https://doi.org/10.1016/j.medengphy.2016.04.016.

21. Croughan MS, Wang DIC. Hydrodynamic Effects on Animal Cells in Microcarrier Bioreactors. Biotechnology 17:213-49 (1991).

22. Liu J, Bi X, Chen T, Zhang, Q, Wang, SX, Chiu, JJ, Liu, GS, Zhang, $Y, B u, P$, Jiang, F. Shear stress regulates endothelial cell autophagy via redox regulation and Sirt1 expression. Cell Death Dis 6: e1827e1827 (2015). http://dx.doi.org/10.1038/cddis.2015.193 


\section{Boschetti et al.}

23. Hossain MS, Bergstrom DJ, Chen XB. A mathematical model and computational framework for three-dimensional chondrocyte cell growth in a porous tissue scaffold placed inside a bi-directional flow perfusion bioreactor. Biotechnol Bioeng 112: 2601-2610 (2015). http://dx.doi.org/10.1016/j.btre.2014.12.002.

24. Nair K, Gandhi M, Khalil S, Chang Yan, K, Marcolongo, M, Barbee, K. Characterization of cell viability during bioprinting processes. Biotechnol J; 4: 1168-1177 (2009). https://doi.org/10.1002/ biot.200900004.

25. Schuerlein S, Schwarz T, Krziminski S, Gätzner, S, Hoppensack, A, Schwedhelm, I, Schweinlin, M, Walles, H, Hansmann, J. A versatile modular bioreactor platform for Tissue Engineering. Biotechnol J 12: 1600326 (2017). https://dx.doi.org/10.1002\%2Fbiot.201600326.

26. FlowKit Ltd. Palabos, CFD, complex physics. http://www.palabos. org/index.php (2012). [accessed 16 October 2017].

27. Wu L, Zhang H, Zhang J, Ding, J. Fabrication of Three-Dimensional Porous Scaffolds of Complicated Shape for Tissue Engineering. I. Compression Molding Based on Flexible-Rigid Combined Mold. Tissue Eng 11: 1105-1114 (2005). https://doi.org/10.1089/ ten.2005.11.1105.

28. Sobral JM, Caridade SG, Sousa RA, Mano, J, Reis, R. Three-dimensional plotted scaffolds with controlled pore size gradients: Effect of scaffold geometry on mechanical performance and cell seeding efficiency. Acta Biomater 7: 1009-1018 (2011). https:// doi.org/10.1016/j.actbio.2010.11.003.

29. Robert McNeel \& Associates. Rhinoceros, modeling tool for designers, Software Package, Ver. 5 SR14 64-bit (5.14.522.8390, 22/5/2017). Seattle, WA (2017).

30. Kurtz A. Intralattice, Generative Lattice Design with Grasshopper. McGill's Additive Design \& Manufacturing Laboratory (ADML). http:// intralattice.com/ (2018) [accessed 26 October 2017].

31. Liu Z, Wu H. Pore-scale modeling of immiscible two-phase flow in complex porous media. Appl Therm Eng 93: 1394-1402 (2016). https://doi.org/10.1016/j.applthermaleng.2015.08.099.

32. Parmigiani A. Lattice Boltzmann calculations of reactive multiphase flows in porous media. Doctoral Thesis. Université de Genève. (2011).

33. Bear J. Dynamics of Fluids in Porous Media. Dover, New York, pp 133 (1972).

34. Salehi-Nik N, Amoabediny G, Pouran B, Tabesh, H, Shokrgozar, MA, Haghighipour, N, Khatibi, N, Anisi, F, Mottaghy, K, Zandieh-Doulabi, B. Engineering Parameters in Bioreactor's Design: A Critical Aspect in Tissue Engineering. Biomed Res Int 2013: 1-15 (2013). http:/l dx.doi.org/10.1155/2013/762132. 